\title{
Transformasi Layanan Perpustakaan Berbasis Media Sosial Dalam Memenuhi Kebutuhan Informasi Kelompok Milenials
}

\author{
Wafi Ariqo \\ Universitas Padjadjaran \\ E-Mail: wafiariqo@gmail.com \\ Yunus Winoto \\ Universitas Padjadjaran \\ E-Mail: yunuswinoto@unpad.ac.id
}

Received: 5-10-2021

Revised: 26-10-2021

Accepted: 03-11-2021

DOI: $10.24036 /$ ib.v3i1.277

\begin{abstract}
The development of information technology has greatly affected people's lives. This can be seen with the use of gadgets that cannot be separated from one's activities in daily life. In addition, one of the other characteristics is the emergence of new media platforms in the community, namely social media platforms. In this regard, the library must always exist in a society that is always dynamic, so that library institutions follow developments around them and are able to transform services according to the needs of the community, especially the millennial group. implementing social media-based library services. This paper tries to discuss about the transformation of social media-based services. The method used is library research method. From the results of the study, it is known that the transformation of library services based on social media is something that must be done in an effort to meet the information needs of the community, especially people from the millennial group. This is because social media has several characteristics such as networking, information, interaction, dissemination and entertainment elements that are in line with the expectations of the millennial group.
\end{abstract}

Keywords: transformation of library services, social media, libraries, information technology.

\begin{abstract}
Abstrak
Terjadinya perkembangan teknologi informasi telah banyak mempengaruhi kehidupan masyarakat. Hal ini terlihat dengan penggunaan gawai yang tidak bisa lepas dalam setiap aktifitas seseorang dalam kehidupan sehari-hari. Selain itu juga salah satu ciri lainnya adalah kemunculan platform media baru di tengah masyarakat yaitu platform media sosial. Berkaitan dengan hal ini perpustakaan agar selalu eksis di tengah masyarakat yang selalu dinamis maka lembaga perpustakaan mengikuti perkembangan yang ada disekitarnya serta mampu melakukan transformasi layanan sesuai dengan kebutuhan masyarakat khususnya kelompok milenials, maka salah satu bentuk transformasi yang harus dilakukan yaitu melakukan pemanfaatan teknologi informasi salah satunya menerapkan layanan perpustakaan yang berbasis media sosial. Tulisan ini mencoba membahas tentang transformasi layanan yang berbasis media social. Metode yang digunakan yaitu metode penelitian kepustakaan (library research). Dari hasil penelitian diketahui bahwa transformasi layanan perpustakaan yang berbasis media sosial merupakan suatu hal yang harus dilakukan dalam upaya memenuhi kebutuhan informasi masyarakat khususnya masyarakat dari kelompok milenials. Hal ini dikarenakan media sosial memiliki beberapa karakteristik seperti jaringan, informasi, interaksi, penyebaran serta unsur hiburan yang sesuai dengan harapan kelompok milenials.
\end{abstract}

Kata kunci: transformasi layanan perpustakaan, media sosial, perpustakaan, teknologi informasi. 


\section{PENDAHULUAN}

Saat ini, kita tengah mengalami suatu perubahan dalam aktivitas sehari-hari yang biasa kita lakukan secara tidak sadar. Perubahan seperti mengecek gawai dipagi hari tatkala raga baru terbangun dari tidurnya, lalu mengunggah segala aktivitas ke dalam media sosial, dan masih banyak lagi. Perlu kita ketahui bersama bahwasanya perubahan ini diakibatkan oleh adanya aktivitas dari penggunaan gawai yang meningkat pesat ditengah masyarakat. Terlebih dengan terus berkembangnya internet dengan kemudahankemudahan dalam aksesibilitasnya, membuat penggunaan gawai setiap harinya akan terus mengalami peningkatan.

Peningkatan penggunaan gawai dan akses internet ini pula tidak terlepas dari adanya perkembangan teknologi di era digital saat ini. Era dimana orang biasa menyebutnya dengan sebutan era revolusi industri 4.0. Pada era revolusi industri $4.0 \mathrm{ini}$, peningkatan serta kemajuan perkembangan teknologi, khususnya pada teknologi telekomunikasi menjadi lebih pesat dalam kemajuannya. Hal ini disebabkan karena banyaknya demand pasar yang sangat tinggi, membuat perusahaan-perusahaan teknologi telekomunikasi khususnya gawai atau biasa disebut dengan gadget ini menjadi terus mengedepankan keinginan pasar dan terus mengembangkan teknologi yang ada pada gawai hasil produksi perusahaan tersebut.

Dengan pesatnya perkembangan teknologi telekomunikasi ini pula lah yang menandai adanya kemunculan platform media baru di tengah masyarakat yaitu platform media sosial. Berdasarkan teori menurut Van Dijk (2013) menjelaskan bahwa media sosial adalah platform media yang memforkuskan pada eksistensi pengguna yang memfasilitasi mereka dalam beraktifitas maupun berkaloborasi. Dengan begitulah, sosial media kini bertransformasi menjadi fasilitator antarpengguna demi menjalin suatu hubungan dan ikatan sosial diantara mereka. 
Kemunculan media sosial ini disambut dengan antusiasme tinggi oleh masyarakat khususnya kaum milenials. Karena populasi masyarakat di Indonesia sendiri, kini lebih didominasi oleh individu-individu dengan rentang umur 16-25 tahun. Dimana kaum milenials sangat ingin membuktikan eksistensi mereka kepada lingkungan sekitarnya atau bahkan kepada seluruh masyarakat Indonesia melalui media sosial tersebut. sehingga, peningkatan aktivitas pada media sosial kini mampu menciptakan suatu kebudayaan baru yang berada pada media siber atau digital. Sebutan untuk budaya ini yaitu cybercultural, dimana budaya siber ini tercipta melalui hasil aktivitas masyarakat yang lebih dominan di dunia maya atau media sosial. Mulai dari update status di facebook, twiter, instagram, lalu posting gambar makanan, atau selfie mereka, hingga story dari apa-apa saja yang mereka lakukan satu hari penuh.

Selain berisi konten-konten pribadi masyarakat, media sosial juga kini menjadi ranah penyebaran informasi yang ada di dalam masyarakat. Namun, dengan adanya persebaran informasi di media sosial ini masyarakat mulai tidak terlalu mempedulikan informasi tersebut yang berbentuk tulisan panjang yang membosankan. Mereka lebih suka kemasan informasi yang lebih menarik karena media sosial yang biasa mereka akses lebih disering diisi dengan konten-konten berbentuk gambar maupun video. Karena dari media sosial itupun juga telah mengubah psikologis masyarakat, dimana minat dan antusiasme mereka dalam membaca kini mulai berkurang. Dampak yang dihasilkan pun membuat kini perpustakaan sepi pengunjung.

Dampak tersebut memperparah stigma di masyarakat bahwa perpustakaan hanyalah sebuah tempat penyimpanan buku, dijaga oleh petugas-petugas yang jutek dan galak, serta tempat yang membosankan. Padahal seiring adanya perkembangan serta kemajuan zaman hingga di era digital ini, perpustakaan senantiasa menyesuaikan dirinya pada perubahanperubahan yang ada di lingkungan 
Published by Program Studi Perpustakaan dan Ilmu Informasi FBS Universitas Negeri Padang, Indonesia

sekitar. Sehingga apabila kita menyebutkan perpustakaan, yang seharusnya kita pahami sekarang ialah satu kesatuan proses dari suatu pelayanan. Dengan adanya kondisi masyarakat diatas itulah, menjadikan media sosial sebagai urgensi bersama dalam proses pelayanan perpustakaan di era digital saat ini.

Perlunya perpustakaan terjun ke dalam ranah media sosial seperti facebook, twitter, dan instagram tidak lain berfungsi untuk menarik perhatian khalayak pengguna media sosial tersebut yang didominasi oleh milenials, serta untuk menghidupkan kembali eksistensi perpustakaan yang kini mulai meredup pada ranah konvensional. Sehingga dari situ, perpustakaan perlu menghadirkan konsep-konsep baru serta gagasangagasan baru dalam pemberian pelayanan kepada masyarakat melalui media sosial ini.

Selain itu, perpustakaan juga tidak boleh melupakan fungsi-fungsi dasar pelayanan yang perlu ada untuk masyarakat seperti yang diungkapkan oleh Sulistyo Basuki (1991) bahwa perpustakaan memiliki lima fungsi dasar yaitu fungsi simpan karya, fungsi informasi, fungsi pendidikan, fungsi rekreasi, dan fungsi kultural. Namun, seiring berkembangnya zaman dengan media sosial tersebut maka perpustakaan juga perlu menghadirkan fungsi baru untuk dapat mempitching masyarakat agar mau berkunjung kembali keperpustakaan seperti fungsi entertain pada produksi film, musik, maupun pagelaran. Melalui fungsi entertain ini diharapkan perpustakaan mampu membentuk kolaborasi antara pustakawan dengan pihak lain untuk lebih berkreasi lagi di dalam media sosial sebagai layanan untuk merangkul masyarakat saat ini.

Pada saat ini, perkembangan media sosial telah menjadi suatu hal yang sangat bombastis. Persebaran pemakaiannya tidak mengenal kata usia dari anak-anak, remaja, hingga dewasa. Hampir disetiap kalangan kini menggunakan sosial media, namun karena di era saat ini pertumbuhan penduduk lebih didominasi oleh milenials, maka penggunaan serta pemakaian media sosial lebih aktif di 
kalangan milenials. Para milenials sendiri pun saling berlomba-lomba berkreasi, berinovasi di media sosial guna untuk memperluas eksistensi mereka di media sosial. Media sosial saat ini memanglah mengasyikkan dan sangat menghibur bagi kita semua selaku masyarakat konsumen dari media sosial itu sendiri.

Namun, seiring dengan pesatnya perkembangan serta pemakaian media sosial, akan terjadi perubahanperubahan psikologis maupun cara berpikir masyarakat khususnya pada kaum milenials. Dimana saat ini, kaum milenials lebih suka melihat instagram atau twitter sebagai sarana konsumsi hiburan sehari-hari, sedangkan minat serta kepekaan mereka terhadap membaca koleksi informasi seperti buku menjadi berkurang. Hal ini disebabkan kurangnya inovasi di dalam perpustakaan itu sendiri, sehingga membuat para pemustaka bosan berlama-lama di dalam perpustakaan. Anggapan-anggapan ini lah yang telah menjadi stigma yang cukup melekat di dalam pikiran masyarakat.
Untuk menghilangkan stigma buruk dimasyarakat, juga untuk mempertahankan eksistensi perpustakaan ditengah arus media sosial yang sangat pesat, maka perpustakaan perlu mengambil langkah untuk ikut terjun langsung ke dalam arus media sosial itu sendiri. Seperti beberapa perpustakaan yang ada di Indonesia sendiri yang salah satunya adalah perpustakaan kemendikbud. Dengan berkolaborasi bersama perpustakaan nasional untuk pelayanan perpustakaan digital via website, perpus kemdikbud juga aktif di dalam media sosial seperti instagram, facebok, dan twitter. Dengan begitu setiap perpustakaan yang ada kini mampu sama-sama berkontribusi aktif di dalam media sosial untuk kembali menumbuhkan minat baca masyarakat.

\section{METODE}

Metode yang dipergunakan dalam penelitian ini menggunakan penelitian kepustakaan (library research). Menurut Amir hamzah $(2020,9)$ disebutkan bahwa penelitian 
Published by Program Studi Perpustakaan dan Ilmu Informasi FBS Universitas Negeri Padang, Indonesia

kepustakaan adalah penelitian kualitatif, bekerja pada tataran analistik dan bersifat perspektif emic, yakni memperoleh data bukan berdasarkan pada persepsi peneliti tetapi berdasarkan fakta-fakta konseptual maupun fakta teoritis. Pendapat yang hampir senagda dikemukakan oleh Mestika Zed (2008, 1-8) yang mengatakan riset Pustaka adalah penelitian yang memanfatakan sumber perpustakaan untuk memperoleh data penelitian. Masih menurut Mestika Zed (2008) ada empat ciri penelitian Pustaka (library research) yakni penelitian berhadapan langsung dengan teks, data pustaka bersiap siap pakai artinya peneliti tidak pergi kemana-mana, data pustaka pada umumnya berupa data sekunder serta kondisi data pustaka tidak dibatasi oleh ruang dan waktu.

Kemudian mengenai pendekatan yang digunakan dalam penelitian kepustakaan ini menggunakan pendekatan interpretative yakni peneliti berangkat dari upaya untuk mencari penjelasan tentang berbagai peristiwa sosial atau budaya yang didasarkan pada perspektif dan pengalaman orang dalam konteks penelitian kepustakaan yang berupa bahan-bahan Pustaka. Sedangkan mengenai tahapan penetian yang dilakukan dalam penelitian kepustakaan ini meliputi tahap perencanaan, tahap pelaksanaan dan hasil akhir, (Hamzah, 2020).

\section{HASIL DAN PEMBAHASAN}

\section{Media Sosial Sebagai Bentuk} Pelayanan Perpustakaan

Perpustakaan saat ini sudah tidak lagi berbicara soal sebuah ruangan tempat penyimpanan buku saja, melainkan lebih dari pada itu perpustakaan kini merupakan sebuah satu kesatuan proses pelayanan kepada pemustaka yang membutuhkan dan mencari informasi. Pelayananpelayanan yang ada di dalam perpustakaan diantaranya seperti pelayanan sirkulasi, pelayanan reference, layanan bimbingan, dan yang lainnya. Melalui pelayanan tersebut perpustakaan memiliki peranan sebagai center of information ditengah 
masyarakat dengan perkembangan teknologi yang pesat seperti saat ini.

Dalam menjalankan peranannya tersebut, perpustakaan perlu mencoba inovasi baru, gaya baru untuk dapat melayani masyarakat khususnya kaum mulenials. Karena di era saat ini, kaum milenial telah mendominasi populasi masyarakat yang ada. Dengan banyaknya kaum milenials di era digital dengan media sosialnya itu, membuat mereka lebih sering aktif di media sosial masing-masing. Hampir 1x24 jam mereka habiskan untuk chatting, scrolling, update status, menonton video, dan lainnya di media sosial. Kebiasaan tersebut kini telah menggerogoti kemampuan literasi mereka terhadap tulisan-tulisan maupun buku-buku sumber informasi yang ada. Karena apa yang disuguhkan dalam media sosial itu lebih didominasi dengan gambar, video, maupun story kegiatan sehari-hari.

Dengan kondisi milenials yang kini aktif di dalam media sosial, perpustakaan mengambil langkah untuk ikut aktif memberikan pelayanan-pelayanan kepada mereka di dalam media sosial. Media sosial ini menjadi suatu media interaktif antara perpustakaan dengan masyarakat khususnya para milenials. Karena melalui sosial media mereka dapat langsung membalas pesan maupun menyapa para potensial user perpustakaan melalui fitur-fitur yang ada di platform media sosial tersebut.

Melalui proses interaktif itu pun, telah mengaburkan batasan-batasan fisik maupun sosials dan milenials pun mampu lebih interaktif lagi dalam menyampaikan pesan-pesannya ke perpustakaan yang dituju. Media sosial sendiri merupakan media yang dapat dikatakan unik, memiliki banyak platform, serta memiliki kemudahankemudahan dalam mengakses setiap platform tersebut. Sehingga itulah mengapa milenials kini lebih sering aktif bersosial media.

Dengan terjunnya perpustakaan memberikan pelayanan baru melalui media sosial ini, maka fungsi serta peranan perpustakaan di era digital saat ini sudah semakin meluas dan tidak terpaku pada pelayananpelayanan yang bersifat konvensional 
Published by Program Studi Perpustakaan dan Ilmu Informasi FBS Universitas Negeri Padang, Indonesia

dengan cara datang langsung ke perpustakaan secara fisik.

Transformasi perpustakaan pun akan semakin berkembang mengarah pada perpustakaan digital serta menghadirkan inovasi baru berupa coworking space dan media sosial seperti saat ini.

Melalui media sosial sendiri, perpustakaan tidak hanya dapat memberikan pelayanan baru kepada para masyarakat khususnya milenials, tetapi juga mampu menjadi suatu sarana promosi untuk meningkatkan eksistensi dari perpustakaan itu sendiri. Karena menurut Nurhadi ia menyatakan bahwa promosi perpustakaan itu merupakan suatu kegiatan yang bertujuan untuk mempropaganda perpustakaan kepada dunia luar dengan sasaran utamanya adalah pemustaka tertentu yang dalam hal ini yaitu para milenials.

Adanya sarana promosi perpustakaan tersebut menjadikan perpustakaan untuk membuka dirinya kepada masyarakat luas, terlebih kepada masyarakat di jagat maya media sosial. Sehingga kedepannya masyarakat jagat maya ini dapat menambah wawasan baru, informasi baru seputar perpustakaan yang mungkin selama ini mereka anggap sebelah mata. Melalui promosi tersebut juga dapat menjelaskan kepada mereka bahwasanya perpustakaan mampu untuk mengikuti tuntutan perubahan zaman dan dapat memberikan pelayanan baru melalui platform media sosial yang sudah banyak tersedia. Dengan demikian, eksistensi dari keberadaan perpustakaan akan terus meningkat serta persebaran informasi untuk masyarakat pun akan terus meluas hingga ke pelosok-pelosok nusantara.

\section{Karakteristik Media Sosial}

Ketika perpustakaan ikut terjun aktif di dalam media sosial untuk memberikan pelayanan kepada pengguna (user) maka pertama-tama yang perlu diperhatikan yaitu karakteristik dari media sosial itu sendiri. Media sosial ini termasuk dalam salah satu platform pada media siber yang ada di era digital saat ini. platform di setiap media siber ini pun memiliki karakteristiknya masing- 
masing. Terlebih karena media sosial muncul beranjak dari sebuah pemahanan bagaimana media tersebut dapat menjadi sarana untuk saling bersosialisasi di dunia maya (virtual).

Karakteristik yang dimiliki media sosial ini merupakan salah satu alasan mengapa kaum milenials kini lebih senang bersosial melalui platform yang ada di media sosial. Tidak hanya itu, media sosial pun sangat melekat pada kegiatan sehari-hari masyarakat di era digital saat ini. Berikut beberapa karakteristik yang dimiliki oleh media sosial, yaitu :

\section{1) Jaringan (Network)}

Media sosial memiliki karakteristik sebagai jaringan, maksudnya ialah melalui media sosial kini sudah terbentuk suatu struktur sosial baru yang berada dalam dimensi virtual yang terbentuk dalam jejaring internet. Jaringan ini membuat interaksi antarpengguna menjadi lebih intens diantara sesama pengguna media sosial. Keseluruhan jaringan ini dimediasikan oleh alat-alat teknologi berupa komputer, tablet, dan gawai (Gadget).

\section{2) Informasi (Information)}

Melalui karakteristik media sosial sebagai wadah dalam tercipta serta penyebaran informasi ini lah yang menjadikan masyarakat kini hampir mengkonsumsi suguhan-suguhan informasi setiap harinya. Munculnya informasi ini, dilatarbelakangi, di produksi, serta disebarluaskan juga oleh para pengguna media sosial itu sendiri. Sehingga pertumbuhan serta persebaran informasi di dalam media sosial ini pun menjadi tak terbendung. Dan disitulah peran perpustakaan sebagai center of information dibutuhkan.

\section{3) Arsip (Archive)}

Karakteristik arsip pada media sosial ini salah satu alasan mengapa milenials kini senang sekali dengan media sosial. Karena melalui karakteristik ini kita dapat memahami bahwa informasiinformasi yang ada di media sosial sudah tersimpan otomatis dan proses mengakses informasi tersebut dapat dilakukan kapan pun dan menggunakan perangkat apa pun itu. 


\section{4) Interaksi (Interacticity)}

Interaksi yang menjadi karakteristik media sosial ini yang telah mengaburkan batasan-batasan fisik maupun sosial bagi perpustakaan untuk menggapai serta menarik perhatian serta minat masyarakat kembali. Interaksi itu biasa dilakukan dengan cara saling membalas komentar, sekadar memberi likes pada unggahan foto pada instagram atau retweet pada unggahan twitter.

\section{5) Penyebaran (Share)}

Media sosial selain digunakan sebagai media untuk memproduksi kontenkonten digital yang dihasilkan oleh para penggunanya itu sendiri, media ini pun digunakan sebagai sarana penyebaran konten digital ataupun informasiinformasi penting seperti informasi mengenai hari-hari besar atau peraturan-peraturan perundangundangan. Tujuannya ialah untuk menyebarkan informasi seluas-luasnya sehingga mampu untuk mengedukasi masyarakat melalui media sosial.

\section{6) Entertainment}

Karakteristik selanjutnya ialah karakteristik entertain atau bersifat menghibur dan berisikan kontenkonten hiburan. Melalui karakteristik inilah banyak bermunculan kontenkonten menarik baik gambar, video, ataupun audio yang tersebar di media sosial melalui produksi para conten creator pengguna sosial media. Dengan begitu, masyarakat memiliki medium baru untuk sekadar merefleksikan kembali pikirannya yang mungkin jenuh dengan pekerjaan ataupun pelajaran yang diterimanya setiap hari. Adanya karakteristik tersebut yang melekat pada media sosial semakin membuat masyarakat khususnya milenials dimanjakan dengan berbagai kemudahan dalam aksesibilitas, mencari hiburan, juga untuk menambah wawasan semata. Untuk itu mengapa perpustakaan perlu terjun ke dalam media sosial, guna membantu juga melayani masyarakat dalam memenuhi kebutuhan-kebutuhan informasi yang mereka butuhkan atau bahkan memberikan hiburan yang belum pernah dilakukan pada perpustakaan fisik.

\section{Standar Pelayanan Melalui Media}

\section{Sosial}


Published by Program Studi Perpustakaan dan Ilmu Informasi

$\begin{array}{ccc}\text { Pada } & \text { perjalanannya dalam } \\ \text { proses } & \text { pengembangan } & \text { suatu }\end{array}$
perpustakaan, standar yang digunakan akan selalu berpacu pada peraturan perundang-undangan yang telah ada. Perundang-undangan yang telah mengatur tentang perpustakaan ini tercantum dalam undang-undang nomor 43 tahun 2007 tentang perpustakaan. Di dalam undangundang tersebut, telah mengatur standar apa saja yang perlu diperhatikan ketika membuat ataupun mengembangkan suatu perpustakaan yang tercantum pada pasal 11 dimana salah satu yang perlu diperhatikan yaitu standar pelayanan perpustakaan.

Standar pelayanan perpustakaan ini akan berbeda pada tiap jenis perpustakaan yang ada. Pelayanan-pelayanannya tersebut pun berada pada konsep konvensional dimana pelayanan itu berjalan langsung di tempat, dengan kata lain pelayanan berlangsung pada perpustakaan secara fisik. Namun, sehubung kini telah memasuki fase dimana hal-hal yang ada disekeliling lingkungan kita mulai beralih dan bertransformasi kepada media digital, maka pelayanan tersebut pun akan ikut beralih fungsi kepada fungsi digital.

Jika melihat apa yang ada saat ini, kita akan lebih mengetahui standar pelayanan yang ada pada perpustakaan yaitu seperti pelayanan pengembangan koleksi, sirkulasi, pengolahan, pelayanan reference, pelayanan bimbingan pencarian informasi, dan yang lainnya. Semua jenis pelayanan yang ada pada standar pelayanan perpustakaan tersebut masih berfungsi secara konvensional di dalam perpustakaan.

Namun, kini muncul media sosial sebagai representasi dari standar pelayanan yang telah diatur didalam undang-undang. Media sosial menjadi suatu sarana baru bagi perpustakaan dalam proses perkembangannya yang harus tetap memerhatikan standarisasi yang telah ada, sedangkan perkembangan zaman yang pesat terus menuntut perpustakaan untuk berinovasi dalam memberikan pelayanannya kepada khalayak ramai dalam hal ini kaum milenials. Adanya urgensi tersebutlah kini perpustakaan 
Published by Program Studi Perpustakaan dan Ilmu Informasi

beralih kepada pelayanan melalui media sosial sebagai standar pelayanannya yang baru.

Urgemsi yang menjadi tantangan bagi perpustakaan untuk mengarungi era digital ini pun tidak hanya berpaku pada berkembangan yang ada, namun ada pula demand serta kebutuhan masyarakat yang tinggi terhadap adanya kehadiran peran perpustakaan pada media sosial. Tuntunan itu pasalnya selaras dengan tujuan yang ada di perpustakaan, menurut Martoatmodjo (1993) tujuan dari pelayanan itu adalah untuk memberikan layanan kepada pengguna (user), dengan cara menghantarkan berbagai informasi kepada penggunanya yang membutuhkan. Namun, tujuan itu tidak berjalan dengan baik pasalnya User kini lebih aktif di dalam media sosial sehingga terjunnya perpustakaan ke dalam media sosial menjadi jawaban tersendiri untuk persoalan yang ada.

Peralihan pelayanan kepada media sosial ini pun tidak terlepas dari suatu perencanaan yang matang. Karena tanpa perencanaan yang baik maka pelayanan yang berjalan pun tidak akan terorganisir dengan baik serta perpustakaan akan sulit dalam mempromosikan serta menaikkan eksistensinya ditengah digitalisme yang sangat pesat. Karena perencanaan itu sendiri diartikan sebagai suatu kegiatan mempelajari maksud dan tujuan dari layanan perpustakaan, juga sebagai kegiatan dalam menghitung dan menentukan biaya kebutuhan dari satu perpustakaan itu sendiri (Penna, 1972: 20).

Dalam perkembangan perpustakaan di Indonesia sendiri, sudah hadir perpustakaan yang terjun ke dalam media sosial yaitu salah satunya ialah perpustakaan kemdikbud. Jika dilihat pada media sosialnya, semua perencanaan yang dilakukan sudah sangat baik dan kita dapat menemukan berbagai jenis layanan baru disana.

\section{Jenis Layanan Dalam Media Sosial}

Perpustakaan dahulu sangat identik dengan definisi sebagai ruangan tempat penyimpanan buku saja, namun kini definisi itu telah jauh berkembang dan berhasil menghadirkan definisi 


\section{Info Bibliotheca}

Published by Program Studi Perpustakaan dan IImu Informasi FBS Universitas Negeri Padang, Indonesia

baru yaitu bahwa perpustakaan saat ini merupakan satu kesatuan dari keseluruhan proses pelayanan informasi kepada masyarakat. Kegiatan layanan itu sendiri, berdasarkan pada apa yang telah di katakan oleh Mary Liu Kao (1992) dalam bukunya Cataloguing And Classification For Library Technicians terdapat dua jenis kegiatan layanan di dalam perpustakaan, antara lain :

a. Layanan Publik

b. Layanan Teknis

Berdasarkan kedua bentuk layanan tersebut yang menjadi perbedaan di antara dua pelayanan diatas terletak pada dimensi pelayanannya. Layanan publik terjadi langsung memberikan pelayanan kepada para pemustaka dengan adanya kontak langsung diantara pustakawan dengan pemustaka. Sedangkan layanan teknis lebih terarah pada kegiatan di bagian belakang layar dari perpustakaan, dengan kata lain berada pada bagian pengolahan serta pengembangan bahan pustaka yang ada.

Selain dua kegiatan diatas, perpustakaan juga identik dengan jenis-jenis layanannya yang ada di dalamnya. Dimana yang kita ketahui bersama saat ini ialah perpustakaan memiliki beberapa jenis layanan yang ada seperti layanan sirkulasi, layanan reference, layanan bimbinganan pembaca, dan yang lainnya. Jenis layanan tersebut termasuk juga kedalam kegiatan layanan publik yang ada di perpustakaan. Sedangkan yang termasuk dalam layanan teknis diantaranya layanan pengembangan koleksi, layanan pengadaan bahan pustaka, dan layanan pengolahan.

Layanan-layanan yang ada saat ini lebih berfokus pada para pengguna yang berkunjung langsung ke dalam perpustakaan. Akan tetapi, ditengah era digital seperti saat ini pengguna lebih sering aktif di dalam dunia virtualnya yaitu pada platform media sosial. Perpustakaan pun turut aktif juga didalamnya, dengan memberikan jenisjenis pelayanan baru melalui sarana media sosial untuk merangkul kembali masyarakat.

Jenis pelayanan baru pada media sosial ini dapat dilihat dari apa yang telah perpustakaan kemdikbud 
lakukan. Dalam media sosial sendiri, perpustakaan kemdikbud hadir di berbagai media sosial mainstream seperti facebook, twitter, dan instagram. Hampir di setiap media sosial yang digunakan oleh perpustakaan kemdikbud aktif semuanya. Namun yang menarik terdapat pada pelayanan mereka di dalam media sosial instagram, dimana pelayanan yang diberikan bukan perihal peminjaman ataupun informasi seputar ilmu-ilmu khusus tertenu. Tetapi, yang terdapat di dalam instagramnya tersebut berupa pelayanan-pelayanan yang lebih interaktif kepada para pengguna (user).

Pelayanan itu berupa Question and Answer (QnA) atau Alkomenu, lalu ada pun kegiatan Giveaway berupa buku-buku bacaan umum untuk follower instagram perpustakaan kemdikbud, mereka juga rutin mengajak user untuk memberikan suatu pernyataan atau pertanyaanpertanyaan yang ingin diajukan kepada perpustakaan kemdikbud melalui fitur yang ada di instagram itu sendiri. Selain itu, mereka juga aktif memberikan informasi kepada para follower maupun non-followers berupa peringatan hari-hari besar yang ada di Indonesia. Juga ada pelayanan berupa livereport kegiatan-kegiatan apa saja yang tengah berlangsung di dalamnya. Terakhir, apa yang di unggah ke dalam instagramnya pun memiliki desaindesain yang menarik perhatian mata para penggunanya.

Melihat proses pelayanan yang ada, membuat perpustakaan kemdibud mampu berinteraksi langsung kepada kaum milenials melalui media sosial yang dimilikinya. Selain mengkampanyekan seruan untuk kembali menumbuhkan minat baca dan memahami lebih lanjut mengenai literasi untuk masyarakat, hal ini juga membuktikan bahwa peranan perpustakaan pada media sosial memiliki pengaruh yang cukup besar kepada masyarakat luas, khususnya kepada mereka-mereka kaum milenials. Dengan begitu, diharapkan kaum milenials ini memiliki semangat serta minat yang tinggi untuk terus tetap melertarikan dan memajukan perpustakaan yang ada dimanapun. 


\section{PENUTUP}

\section{Simpulan}

Perkembangan zaman yang pesat, kemajuan teknologi yang semakin meningkat, membuat keseluruhan sistem yang ada kian bertransformasi menjadi digital. Tak hanya itu, aktivitas sehari-hari yang dilakukan oleh masyarakat pun tidak terlepas dari teknologi yang ada seperti Gadget atau gawai. Ditambah lagi, kini telah terjadi ledakan populasi penduduk yang berdampat pada munculnya dominasi klasifikasi masyarakat oleh kaum milenials. Dimana mereka yang termasuk dalam kategori millenials ini lebih banyak berada pada rentang umur 16-25 tahun.

Pesatnya teknologi khususnya pada bidang telekomunikasi, menciptakan suatu dobrakan baru dengan menghadirkan media sosial. Media sosial ini memiliki beberapa platform seperti facebook, twitter, dan instagram. Kemunculannya ini tepat ketika populasi masyarakat didominasi oleh kaum milenials, sehingga penggunaannya pun semakin meningkat. Adanya peningkatan tersebut kemudian menciptakan suatu budaya baru, dimana budaya ini terbentuk melalui proses interaksi sosial di dunia virtual atau biasa disebut dengan dunia maya yaitu budaya siber (cybercultural).

Namun, seiring dengan hal-hal yang telah terjadi tersebut membuat perpustakaan kini kian sepi untuk dikunjungi oleh masyarakat dalam hal ini kaum milenials. Karena habits mereka sendiri yang kini sudah melekat pada media sosial, membuat mereka lebih nyaman menghabiskan waktu berlama-lama disana dan bukan lagi di dalam perpustakaan. Melihat permasalahan tersebut, menjadikan perpustakaan memiliki urgensi baru dalam proses pengembangan pelayanannya. Dimana kini mereka perlu terjun aktif kedalam media sosial untuk mentransformasi layanan yang diberikan kepada masyarakat.

Dengan mempersiapkan segala perencanaan yang matang, juga konsep serta materi dan bentuk pelayanan seperti apa yang ingin diberikan kepada masyarakat, perpustakaan kini 
menjadi lebih siap untuk mengokohkan eksistensinya di jagat dunia maya. Karena melalui media sosial perpustakaan dapat meningkatkan eksistensinya ditengah era digital seperti saat ini juga mampu menjadikan sarana untuk mengkampanyekan pentingnya literasi bagi masyarakat. Melalui media sosial juga, proses pelayanan yang diberikan akan menjadi lebih interaktif lagi antara pengguna (user) atau followers dengan pengelola perpustakaan.

Melalui penyajian pelayanan yang menarik seperti Question and Answer (QnA), Giveaway buku-buku bacaan umum, memberika kesempatan kepada pengikut media sosial untuk memberikan kritik, saran, serta masukannya untuk perpustakaan terkait, adanya livereport untuk kegiatan-kegiatan internal maupun eksternal yang dilakukan perpustakaan. Dengan begitu maka proses interakftif ini sudah berhasil mengaburkan batasan-batasan yang ada baik secara fisik maupun sosial diantara perpustakaan dengan pemustaka atau User.
Dengan demikian, pelayanan yang mampu diberikan oleh perpustakaan kepada para pengguna akan menjadi lebih optimal dengan mampu melayanan secara cepat, tepat, dan tanggap. Kenyamanan serta kepentingan pengguna menjadi prioritas pertama dalam berjalannya perpustakaan melalui media sosial, guna memenuhi kebutuhan-kebutuhan pengguna dalam hal ini kaum milenials akan informasi yang dibutuhkan oleh mereka.

\section{DAFTAR PUSTAKA}

Hamzah, Amir. (2020). Metode Penelitian Kepustakaan (Libraray Research), Malang : Literasi Nusantara.

Haryanto. (2015). Pemanfaatan Media Sosial Sebagai Media Komunikasi Komunitas Pustakawan Homogen Dalam Rangka Pemanfaatan Bersama Koleksi Antar Perguruan Tinggi. EduLib, 5(1), 83-89.

Lasa Hs. (2015). STANDAR PELAYAAN PERPUSTAKAAN PERGURUAN TINGGI: Aspek Akreditasi BAN PT dan Akreditasi PNRI. In Standar Pelayanan Minimal (SPM) Perpustakaan UGM. Yogyakarta.

Nasrullah, R. (2017). Etnografi Virtual. 


\section{Info Bibliotheca}

Bandung: Sambiosa Rekatama Media.

Nasrullah, R. (2018). Riset khalayak digital: perspektif khalayak media dan realitas virtual di media sosial. Jurnal Sosioteknologi, 17(2), 271-287.

Pratama, F. J. (2019). PENGGUNAAN MEDIA SOSIAL INSTAGRAM DI BADAN NASIONAL PENGELOLA PERBATASAN REPUBLIK INDONESIA DALAM PENYEBARAN INFORMASI, 1-27.

Rohanda dan Yunus Winoto (2019). Analisis Bibliometrika Tingkat Kolaborasi, Produktivitas Penulis, Serta Profil Artikel Jurnal Kajian Informasi \& Perpustakaan Tahun 20142018, Jurnal Pustabiblia, Vol 3 Nomor 2 Tahun 2019.

Sujatna. (2018). Promosi Perpustakaan.
Kota Tanggerang: Mahara Publishing.

Sukaesih, \& Winoto, Y. (2019). DasarDasar Pelayanan Perpustakaan (cet. 1). Kebumen: CV. Intishar Publishing.

UU RI no.43. Undang-Undang Republik Indonesia Nomor 43 Tahun 2007 Tentang Perpustakaan.

Winoto, Yunus dan Sukaesih. (2016). Studi Tentang Pengembangan Koleksi Pada Perpustakaan PT di Wilayah Priangan Timur Provinsi Jawa Barat, Jurnal Khizanah Al Hikmah, Vol 4 Nomor 2 tahun 2016.

Zed, Mestika. (2008). Metode Penelitian Kepustakaan, Jakarta : Yayasan Obor Indonesia. 